\title{
Canine hepatozoonosis in southeastern Bahia, Brazil
}

\author{
T.V. Harvey ${ }^{1}$, P.E.B. Guedes ${ }^{1}$, T.N.A. Oliveira ${ }^{1}$, M.S. Assunção ${ }^{2}$, \\ F.S. Carvalho ${ }^{1}$, G.R. Albuquerque ${ }^{3}$, F.L. Silva ${ }^{3}$ and R.S.A. Carlos ${ }^{3}$ \\ ${ }^{1}$ Programa de Pós-Graduação em Ciência Animal, \\ Universidade Estadual de Santa Cruz, Ilhéus, BA, Brasil \\ ${ }^{2}$ Graduação em Medicina Veterinária, Universidade Estadual de Santa Cruz, \\ Ilhéus, BA, Brasil \\ ${ }^{3}$ Departamento de Ciências Agrárias e Ambientais, \\ Universidade Estadual de Santa Cruz, Ilhéus, BA, Brasil \\ Corresponding author: R.S.A. Carlos \\ E-mail: rsacarlos@uesc.br
}

Genet. Mol. Res. 15 (3): gmr.15038623

Received March 21, 2016

Accepted April 8, 2016

Published August 18, 2016

DOI http://dx.doi.org/10.4238/gmr.15038623

Copyright (C) 2016 The Authors. This is an open-access article distributed under the terms of the Creative Commons Attribution ShareAlike (CC BY-SA) 4.0 License.

\begin{abstract}
In Brazil, canine hepatozoonosis is a tick-borne subclinical hemoparasitosis caused by a protozoa Hepatozoon canis and is highly prevalent in dogs in rural areas. An epizootiological study was conducted to investigate the prevalence of $H$. canis in the canine population of Ituberá, Bahia, and to analyze any associated risk factors. Blood samples were collected from 380 dogs and determined the presence of the protozoan by performing capillary blood smear and polymerase chain reaction (PCR). Epizootiological data were collected by asking dog owners to answer a structured questionnaire. $H$. canis gamonts were not detected in the blood smears. However, PCR detected H. canis in 163/380 (42.9\%) dogs examined. Physical examination and anamnesis indicated 105 (64.4\%) positive asymptomatic dogs.
\end{abstract}


Hematological alterations were observed in $115(70.5 \%)$ infected dogs. No clinical, hematological, or epizootiological variable was found to be significantly associated to the infection. In conclusion, the high prevalence of $H$. canis infection in local dogs may be because of the peri-urban features of this municipality. Moreover, to the best of our knowledge, this study the first study to report $H$. canis infection in the State of Bahia.

Key words: Blood parasites; Epizootiology; Dogs; Ticks; Northeastern Brazil

\section{INTRODUCTION}

Canine hepatozoonosis is a tick-borne disease caused by the intraleukocytic protozoans Hepatozoon canis and Hepatozoon americanum. Infections develop after the ingestion of ticks containing mature oocysts in their hemocoel (Baneth et al., 2003). This infection is prevalent in subtropical, tropical and temperate areas (Menn et al., 2010; de Miranda et al., 2014) and is mainly transmitted by the tick Rhipicephalus sanguineus (Baneth and Weigler, 1997). However, some studies have suggested that canine hepatozoonosis is also transmitted by Amblyomma spp and R. (Boophilus) microplus (Forlano et al., 2005; Rubini et al., 2009; de Miranda et al., 2011).

Worldwide, the prevalence of canine hepatozoonosis varies between 2.2 and $44.7 \%$ (Criado-Fornelio et al., 2007; Menn et al., 2010). In Brazil, the prevalence of this infection has been reported in several states with higher prevalence in dogs in rural areas (O'Dwyer et al., 2001; Rubini et al., 2008; de Miranda et al., 2014), with prevalence rates varying between 0.49 and $79.2 \%$ (Ramos et al., 2010; de Miranda et al., 2014). Variation in the prevalence of this infection depends on the state, the place of origin of dogs (urban or rural), and diagnostic method (O'Dwyer, 2011). Some studies have also reported that the age and sex of the dogs are risk factors for the infection (Gomes et al., 2010; de Miranda et al., 2014). However, some other studies have not observed such association (Abd Rani et al., 2011; Hornok et al., 2013).

In Brazil, most dogs with canine hepatozoonosis develop a subclinical infection characterized by low parasitemia (O’Dwyer, 2011). However, clinical and hematological alterations such as weight loss, pale mucous membranes, hyperthermia, anorexia, diarrhea, gait abnormalities, polyuria, polydipsia, anemia, leukocytosis with neutrophilia and thrombocytopenia have also been reported (Gondim et al., 1998; Paludo et al., 2003; Aguiar et al., 2004; Mundim et al., 2008; Marchetti et al., 2009).

H. canis infection is routinely dignosed by detecting gamonts in neutrophils or monocytes by performing blood or buffy coat smear examination. However, low sensitivity of this test, in case of low or intermittent parasitemia, indicates the need for more sensitive methods such as serological and molecular assays (Baneth et al., 1998; Mylonakis et al., 2005; Otranto et al., 2011; Kelly et al., 2013).

To date, no studies have been performed on the prevalence and epizootiology of canine hepatozoonosis in the State of Bahia, Brazil. Therefore, the present study investigated the prevalence of $H$. canis in dogs from the municipality of Ituberá in southeastern Bahia, and determined the possible risk factors and the clinical and hematological alterations associated with this infection.

Genetics and Molecular Research 15 (3): gmr.15038623 


\section{MATERIAL AND METHODS}

\section{Study area}

This cross-sectional study was conducted in the municipality of Ituberá, located in the mesoregion of southern Bahia and microregion of Valença, within the Atlantic forest biome (13 $43^{\prime} \mathrm{S} 39^{\circ} 08^{\prime} \mathrm{W}$ ) (Figure 1). The municipality has an area of $417.274 \mathrm{~km}^{2}$, and includes approximately 26,591 inhabitants, with a demographic density of 63.73 inhabitants/ $\mathrm{km}^{2}$ (IBGE, 2010). The region has a humid tropical climate, with an average temperature of $25.3^{\circ} \mathrm{C}$, annual thermal amplitude of $5.6^{\circ} \mathrm{C}$ and annual rainfall of $1.800-2.400 \mathrm{~mm}$. This study was approved by the Ethics Committee for the Use of Animals of the Santa Cruz State University under protocol number 028/2012.
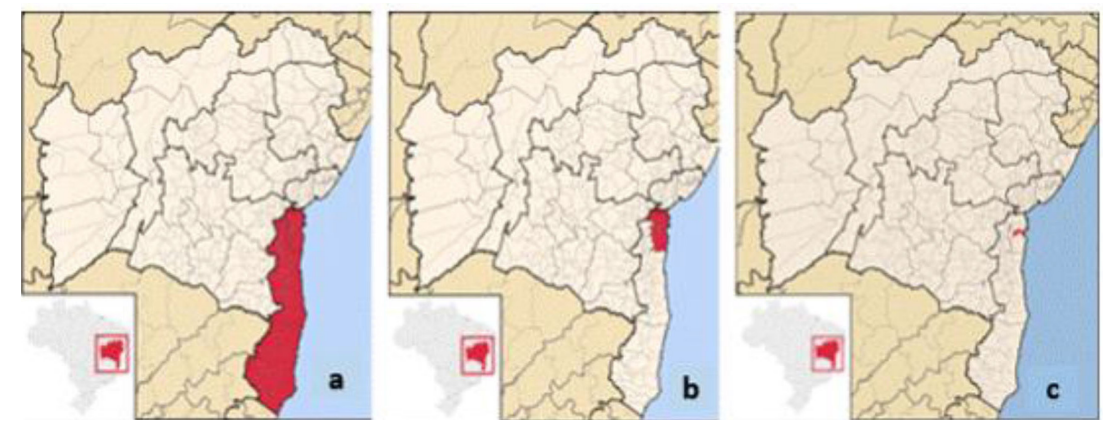

Figure 1. a. Mesoregion of southern Bahia, b. microregion of Valença, c. municipality of Ituberá, Bahia [http:// pt.wikipedia.org].

\section{Study animals}

The sample size of dogs to be included in the study was calculated using the Sourceforge ${ }^{\circledR}$ software (DHI Group, Inc.), by considering the size of the canine population in Ituberá as $10 \%$ of the size of the human population (Cifuentes, 1988). The number of the studied animals was determined by setting the prevalence rate at $50 \%$, with a confidence interval (CI) of $95 \%$ and error margin of $5 \%$. The study was performed from May to September 2012 and evaluated 380 semi-restricted adult dogs aged $>1$ year, after obtaining their owner's authorization. Blood samples were collected equally by covering both urban (326 dogs) and rural (54 dogs) areas of the municipality. A maximum of two dogs per household was assessed.

\section{Collection of clinical and epizootiological data collection}

All the dogs included in this study were evaluated for the presence of ticks and clinical signs of $H$. canis infection, such as anemia, anorexia, paleness of mucous membranes, weight loss, diarrhea, vomit, dehydration, and fever. All data were recorded in individual records.

In addition, all dog owners were asked to answer a structured questionnaire to determine risk factors associated to the infection. Variables such as tick infestation, habitat, habit of sleeping away from home, contact with other dogs, age, and sex were analyzed.

Genetics and Molecular Research 15 (3): gmr.15038623 


\section{Blood sampling}

A blood sample $(5 \mathrm{~mL})$ was collected from each dog by performing jugular or cephalic vein puncture, and stored in EDTA-containing tubes; the blood samples were aliquoted into DNase/RNase-free microtubes to perform hematological and molecular analysis. After hematological analysis, the blood samples were centrifuged at $1650 \mathrm{~g}$ for $10 \mathrm{~min}$ (LS - 3 Plus $^{\text {TM }}$, CELM, São Paulo, Brazil). The buffy coat obtained by centrifugation was separated, identified, and frozen at $-20^{\circ} \mathrm{C}$.

In addition, blood samples were collected from the peripheral eartip of the dogs by performing needle puncture $(30 \times 7 \mathrm{~mm})$ to prepare blood smears for detecting the parasite.

These analysis were performed in the Laboratory of Clinical Pathology of the Veterinary Hospital of the Santa Cruz State University.

\section{Hematological analysis}

Hematological parameters such as erythrocyte, leukocyte, and platelet numbers and hematocrit values were analyzed using Automatic Accountant of Sanguine Cells ABC Vet ${ }^{\mathrm{TM}}$ (HORIBA, UK). Anemia, thrombocytopenia, leukocytosis, and/or leukopenia were considered as canine hepatozoonosis-associated hematological alterations associated with the infection. Dogs with hematocrit value below $37 \%$ were considered anemic, dogs with platelet counts less than $2 \times 10^{5} / \mathrm{mL}$ were considered thrombocytopenic and dogs with global leukocyte count below $7 \times 10^{3} / \mathrm{mL}$ were considered leukopenic (Jain, 1993). Specific granulocyte and agranulocyte counts were determined manually by performing microscopic analysis of DiffQuick-stained blood smears.

\section{Cytological examination}

To identify intracellular inclusions of $H$. canis, blood smears were prepared on glass slides and stained with Diff-Quick. The whole stained smears were examined under a light microscope (Primo Star ${ }^{\mathrm{TM}}$, ZEISS, Germany), with 40-X oil immersion objective.

\section{DNA extraction, amplification, and sequencing}

DNA was extracted individually from the buffy coat by using a commercial kit Easy$\mathrm{DNA}^{\mathrm{TM}}$ (Invitrogen, Carlsbad, CA, USA), according to the manufacturer's guidelines.

A fragment of the $18 \mathrm{~S}$ rRNA gene ( $574 \mathrm{bp}$ ) was amplified by performing convencional PCR, with primers HEP144-169 (5'-GGTAATTCTAGAGCTAATA-3') and HEP743-718 (5'-ACAATAAAGTAAAAAACA-3'), by using a protocol by Spolidorio et al. (2011). PCR were performed in a $25-\mu \mathrm{L}$ reaction mixture containing the extracted DNA, $1 \mathrm{X}$ PCR buffer, $3.5 \mathrm{mM} \mathrm{MgCl} 2,0.2 \mathrm{mM}$ dNTPs, $2.5 \mathrm{U}$ Taq DNA polymerase and $0.4 \mathrm{mM}$ of each primer. The amplification was performed in Veriti ${ }^{\mathrm{TM}}$ ThermalCycler (Applied Biosystems, Foster City, CA, USA), by using the following protocol: initial denaturation step at $95^{\circ} \mathrm{C}$ for $5 \mathrm{~min} ; 35$ cycles of denaturation at $95^{\circ} \mathrm{C}$ for $30 \mathrm{~s}$, annealing at $50^{\circ} \mathrm{C}$ for $30 \mathrm{~s}$, and extension at $72^{\circ} \mathrm{C}$ for $60 \mathrm{~s}$; and a final extension was performed at $72^{\circ} \mathrm{C}$ for $5 \mathrm{~min}$. DNA of a dog infected with a Hepatozoon sp was used as a positive control, and ultrapure water was used as a negative control. The amplicons obtained ( $10 \mu \mathrm{L} /$ sample) were electrophoresed on a $1.5 \%$ agarose gel

Genetics and Molecular Research 15 (3): gmr.15038623 
(75 V and $40 \mathrm{~min}$ ) stained with $0.1 \mu \mathrm{g} / \mathrm{mL} \mathrm{SYBER}^{\mathrm{TM}}$ Safe DNA Gel Stain (Invitrogen) and were visualized under a transiluminator (L.PIX ${ }^{\mathrm{TM}}$, LOCCUS Biotecnologia, São Paulo, Brasil).

These analyses were performed in the Laboratory of Animal Genetic of the Veterinary Hospital of the Santa Cruz State University.

One amplicon considered positive was subjected to purification process using the PureLink ${ }^{\circledR}$-Quick Gel Extraction kit and PCR Purification kit (Invitrogen) and was sent to the Ludwig Biotec Company (Porto Alegre, RS, Brazil) for sequencing in both directions using internal primers. The sequence was compared with $18 \mathrm{~S}$ rRNA gene sequences of $H$. canis available in GenBank.

\section{Statistical analysis}

Prevalence and $95 \%$ binomial exact Cis were calculated using Sourceforge.net ${ }^{\mathrm{TM}}$ (http://sampsize.sourceforge.net/iface/index.html).

The association of $H$. canis infection with clinical and hematological abnormalities and other risk factors was evaluated by performing univariate analysis with the chi-square test or the Fisher exact test (at 5\% level of significance and 95\% CI). Variables significant at $\mathrm{P} \leq 0.20$ were included in the multiple-logistic regression analysis. All statistical analyses were conducted using the Epi-Info ${ }^{\mathrm{TM}}$ version 7.1.5.2 software. Mean hematocrit values of the infected and uninfected animals were compared using the Student $t$-test.

\section{RESULTS}

\section{Cytological and molecular analysis}

Gamonts of $H$. canis were not detected in blood smears. However, molecular analysis using extracted DNA detected $H$. canis in $163 / 380$ dogs analyzed $(42.9 ; 95 \% \mathrm{CI}=37.85-48.04)$.

At the BLAST analysis the sequenced amplicon was $99 \%$ identical with those of $H$. canis available in GenBank (AY150067.2, AY461375.2, AY864677.1).

\section{Clinical data}

Results of PCR were considered for analyzing clinical and hematological data. Of the 163 dogs infected with $H$. canis, 48 (29.4\%) were found to be infested with ticks during clinical examination. Clinical and hematological abnormalities together indicated that $17 / 163$ (10.4\%) dogs showed clinical signs, 74/163 (45.4\%) dogs had hematological alterations, 41/163 (25.2\%) dogs presented clinical signs and hematological alterations, and $31 / 163(19 \%)$ dogs had no alterations. Classification of the infected dogs into symptomatic and asymptomatic groups showed that $58(35.6 \%)$ dogs presented clinical signs, including dehydration, lymphadenomegaly, diarrhea and vomiting, with or without hematological alterations. In all, $105(64.4 \%)$ dogs were asymptomatic. However, none of these clinical signs was significantly associated with $H$. canis infection.

\section{Hematological analysis}

Of the 163 positive dogs that were confirmed as having the infection by PCR, 115

Genetics and Molecular Research 15 (3): gmr.15038623 
T.V. Harvey et al.

(70.5\%) dogs showed hematological abnormalities, with or without clinical signs. Of these 115 dogs, 76 (66.1\%) had thrombocytopenia, 47 (40.9\%) had anemia, 40 (34.8\%) had leukocytosis, and $10(8.7 \%)$ had leukopenia. However, none of these hematological alterations was significantly associated with $H$. canis infection.

\section{Risk factors}

Of the 163 infected dogs, $144(88.3 \%)$ were from urban areas and $19(11.7 \%)$ were from rural areas. In all, $113(69.3 \%)$ dogs were aged between 0 and 4 years and $50(30.7 \%)$ dogs were aged $>4$ years. Further, 103/163 (63.2\%) dogs were males and 60/163 (36.8\%) dogs were females. Despite the high prevalence of $H$. canis infection in male dogs, no statistically significant association was detected. Variables such as age, sex, race, habitat, contact with other dogs, tick infestation, and habit of sleeping away from home were not found to be the risk factors of $H$. canis infection (Table 1).

Table 1. Frequency of variables such as tick infestation, habitat, age, sex, contact with other dogs and habit of sleeping away from home, in dogs infected with Hepatozoon canis in southeastern Bahia, Brazil.

\begin{tabular}{|c|c|c|c|c|c|c|c|c|}
\hline \multirow[t]{2}{*}{ Variable } & \multicolumn{3}{|c|}{ Positive H. canis dogs } & \multicolumn{2}{|c|}{ Negative $H$. canis dogs } & \multirow[t]{2}{*}{ Total } & \multirow[t]{2}{*}{$\mathrm{P}$ value } & \multirow[t]{2}{*}{ OR } \\
\hline & & $\mathrm{N}$ & $\%$ & $\mathrm{~N}$ & $\%$ & & & \\
\hline \multirow[t]{2}{*}{ Tick infestation } & Yes & 48 & 29.4 & 67 & 30.9 & 115 & 0.81 & 0.93 \\
\hline & No & 115 & 70.6 & 150 & 69.1 & 265 & & \\
\hline \multirow[t]{2}{*}{ Habitat } & Urban & 144 & 88.3 & 182 & 83.9 & 326 & 0.25 & 1.45 \\
\hline & Rural & 19 & 11.7 & 35 & 16.1 & 54 & & \\
\hline \multirow[t]{2}{*}{ Sex } & $\mathrm{F}$ & 60 & 36.8 & 83 & 38.2 & 143 & 0.61 & 1.06 \\
\hline & M & 103 & 63.2 & 134 & 61.8 & 237 & & \\
\hline \multirow[t]{2}{*}{ Age } & $0-4$ years & 113 & 69.3 & 152 & 70.0 & 265 & 0.96 & 1.03 \\
\hline & $>4$ years & 50 & 30.7 & 65 & 30.0 & 115 & & \\
\hline \multirow[t]{2}{*}{ Contact with other dogs } & Yes & 117 & 71.8 & 162 & 74.7 & 279 & 0.74 & 0.86 \\
\hline & No & 46 & 28.2 & 55 & 25.3 & 101 & & \\
\hline \multirow[t]{2}{*}{ Habit of sleeping away from home } & Yes & 50 & 30.7 & 49 & 22.6 & 99 & 0.07 & 1.51 \\
\hline & No & 113 & 69.3 & 168 & 77.4 & 281 & & \\
\hline
\end{tabular}

$\mathrm{N}=$ number of animals, $\mathrm{OR}=$ odds ratio, $\mathrm{F}=$ female, $\mathrm{M}=$ male.

\section{DISCUSSION}

The municipality of Ituberá is located in the coastal forests of Bahia, an Atlantic forest ecoregion, where the climatic conditions favor the biogeographic dispersion of ticks and thus the establishment of hemoparasitosis as the Brazilian canine hepatozooosis.

In the present study, cytological analysis of the blood samples yielded negative results for H. canis infection, which was similar to that reported by Sasaki et al. (2008), who did not detected H. canis gamonts in the blood smears of 400 dogs. Absence of H. canis gamonts in the blood smears may be because of the low sensitivity of the technique and/or because of low or intermittent parasitemia in the dogs in this region (Baneth et al., 1998). This result suggests the presence of a chronic infection in the canine population of Ituberá, which decreases the chance of detecting the pathogen in the blood smears. O'Dwyer (2011) observed that in some infected dogs, the gamonts disappeared from the bloodstream, thus preventing their detection by the routine method.

Molecular analysis showed high prevalence of $H$. canis infection (42.9\%). This result is consistent with that of a study by Chiareli (2009) that detected the infection in $37.9 \%$ (71/187) of dogs examined, and with that of a study by Spolidorio et al. (2010) that detected

Genetics and Molecular Research 15 (3): gmr.15038623 
the infection in 58.7\% (54/92) of dogs examined. According to Miyama et al. (2005), a positive PCR result is indicative of the infection. PCR analysis performed in our study was sufficiently sensitive to detect $H$. canis infection in asymptomatic dogs, with subclinical and chronic infection associated with low parasitemia. Moreover, PCR was more sensitive than the routine method in detecting the infection, as verified by Rubini et al. (2008), and the use of buffy coat to performe the molecular analysis may have contributed to rise the positive results by PCR. During sample collection, it was observed that all urban neighborhoods possessed rural characteristics such as presence of small orchard and vegetable gardens and raising farm animals. Therefore, high prevalence of the infection may be related to the rural profile of the municipality as observed in previous studies on dogs from Brazilian rural communities (O’Dwyeret al., 2001; Rubini et al., 2008; de Miranda et al., 2014).

Most dogs that yielded positive results for PCR analysis were asymptomatics (64.4\%). This result was consistent with those of studies performed by Vojta et al. (2009), Abd Rani et al. (2011), O'Dwyer (2011), and de Miranda et al. (2014), which showed that most animals infected with $H$. canis were apparently healthy. Detection of the infection in large number of asymptomatic animals also suggests the presence of a chronic infection in that canine population, which is common in endemic areas (Almosny, 2002). Moreover, absence of a significant association of clinical signs or hematological alterations with $H$. canis infection indicates that the pathogen has low pathogenicity in that canine population.

Hematological analysis showed that 115/163 (70.5\%) dogs had alterations such as anemia, leukocytosis with neutrophilia, leukopenia, and thrombocytopenia. Of these alterations, thrombocytopenia was the most frequent hematological alteration, wich was detected in $46.6 \%$ dogs. However, studies by Gondim et al. (1998) and Mundim et al. (2008) reported anemia as the most frequent hematological alteration. In contrast, studies by O'Dwyer et al. (2006) and Lasta et al. (2009) did not detected significant hematological and biochemical alterations in dogs evaluated from Botucatu and Porto Alegre, respectively, which was similar to that observed in the present study. According to O'Dwyer (2011), hematological abnormalities, even if having significant association with $H$. canis infection can be related to coinfection with other blood parasites. This author also affirms that, in Brazil, clinical signs and the hematological alterations cannot be exclusively associated with the $H$. canis infection. Moreover, agents such as Ehrlichia canis were previously identified in the State of Bahia (Carlos et al., 2011; Guedes et al., 2015).

Few studies have described the epizootiology of the H. canis infection in Brazil. In this study, variables such as sex, age, race, tick infestation, habitat, contact with other dog, and habit of sleeping away from home did not constitute risk factors of $H$. canis infection. Association between tick infestation and $H$. canis infection was not significant, possibly because of the establishment of a chronic infection in this canine population. In such a case, identification of the vector during clinical examination is not a determinant of infection. Furthermore, similarity between the environmental conditions and handling of the animals in the urban and rural areas of the municipality of Ituberá might have contributed to this result.

In conclusion, the canine population of southeastern Bahia is infected with H. canis, with most infected dogs being asymptomatic and having subclinical and/or chronic infection. High prevalence of the infection, as determined by PCR, low parasitemia and high number of asymptomatic dogs indicate the low pathogenicity of $H$. canis in this canine population. Our results indicate that PCR is a fundamental method for diagnosing the prevalence of $\mathrm{H}$. canis in asymptomatic animals.

Genetics and Molecular Research 15 (3): gmr.15038623 


\section{ACKNOWLEDGMENTS}

Research supported by CAPES (Federal Agency for the Support and Improvement of Higher Education), FAPESB (Foundation for Research Support for State of Bahia), and by UESC (Santa Cruz State University). We also thank Dr. Fernando Spagnol for providing the positive control for $H$. canis infection.

\section{REFERENCES}

Abd Rani PAM, Irwin PJ, Coleman GT, Gatne M, et al. (2011). A survey of canine tick-borne diseases in India. Parasit. Vectors 4: 141. http://dx.doi.org/10.1186/1756-3305-4-141

Aguiar DM, Ribeiro MG, Silva WB, Dias Júnior JG, et al. (2004). Hepatozoonose canina: achados clínico-epidemiológicos em três casos. Arq. Bras. Med. Vet. Zootec 56: 411-413. http://dx.doi.org/10.1590/S0102-09352004000300021

Almosny NRP (2002). Hemoparasitoses em Pequenos Animais Domésticos e como Zoonoses. 1st edn. L.F. Livros, Rio de Janeiro.

Baneth G and Weigler B (1997). Retrospective case-control study of hepatozoonosis in dogs in Israel. J. Vet. Intern. Med. 11: 365-370. http://dx.doi.org/10.1111/j.1939-1676.1997.tb00482.x

Baneth G, Shkap V, Samish M, Pipano E, et al. (1998). Antibody response to Hepatozoon canis in experimentally infected dogs. Vet. Parasitol. 74: 299-305.http://dx.doi.org/10.1016/S0304-4017(97)00160-X

Baneth G, Mathew JS, Shkap V, Macintire DK, et al. (2003). Canine hepatozoonosis: two disease syndromes caused by separate Hepatozoon spp. Trends Parasitol. 19: 27-31.http://dx.doi.org/10.1016/S1471-4922(02)00016-8

Carlos RSA, Carvalho FS, Wenceslau AA, Almosny NRP, et al. (2011). Risk factors and clinical disorders of canine ehrlichiosis in the South of Bahia, Brazil. Rev. Bras. Parasitol. Vet. 20: 210-214. http://dx.doi.org/10.1590/S198429612011000300006

Chiareli RA (2009). Investigação clínico-laboratorial e molecular da infecção por Hepatozoon canis em cães da região periurbana de Brasília. Master's thesis, UnB, Brasília. Disponível em http://repositorio.unb.br/handle/10482/8246. Acessado em Dezebro de 2014.

Cifuentes EE (1988). Program for the elimination of urban rabies in LatinAmerica. Rev. Infect. Dis. 10: 689-692. http:// dx.doi.org/10.1093/clinids/10.Supplement 4.S689

Criado-Fornelio A, Rey-Valeiron C, Buling A, Barba-Carretero JC, et al. (2007). New advances in molecular epizootiology of canine hematic protozoa from Venezuela, Thailand and Spain. Vet. Parasitol. 144: 261-269. http://dx.doi. org/10.1016/j.vetpar.2006.09.042

de Miranda RL, de Castro JR, Olegário MMM, Beletti ME, et al. (2011). Oocysts of Hepatozoon canis in Rhipicephalus (Boophilus) microplus collected from a naturally infected dog. Vet. Parasitol. 177: 392-396. http://dx.doi. org/10.1016/j.vetpar.2011.01.044

de Miranda RL, O'Dwyer LH, de Castro JR, Metzger B, et al. (2014). Prevalence and molecular characterization of Hepatozoon canis in dogs from urban and rural areas in Southeast Brazil. Res. Vet. Sci. 97: 325-328. http://dx.doi. org/10.1016/j.rvsc.2014.06.015

Forlano M, Scofield A, Elisei C, Fernandes KR, et al. (2005). Diagnosis of Hepatozoon spp. in Amblyomma ovale and its experimental transmission in domestic dogs in Brazil. Vet. Parasitol. 134: 1-7. http://dx.doi.org/10.1016/j. vetpar.2005.05.066

Gomes PV, Mundim MJS, Mundim AV, de Ávila DF, et al. (2010). Occurrence of Hepatozoon sp. in dogs in the urban area originating from a municipality in southeastern Brazil. Vet. Parasitol. 174: 155-161.http://dx.doi.org/10.1016/j. vetpar.2010.07.020

Gondim LF, Kohayagawa A, Alencar NX, Biondo AW, et al. (1998). Canine hepatozoonosis in Brazil: description of eight naturally occurring cases. Vet. Parasitol. 74: 319-323.http://dx.doi.org/10.1016/S0304-4017(96)01120-X

Guedes PEB, Oliveira TNA, Carvalho FS, Carlos RSA, et al. (2015). Canine ehrlichiosis: prevalence and epidemiology in northeast Brazil. Rev. Bras. Parasitol. Vet. 24: 115-121.http://dx.doi.org/10.1590/S1984-29612015030

Hornok S, Tánczos B, Fernández de Mera IG, de la Fuente J, et al. (2013). High prevalence of Hepatozoon-infection among shepherd dogs in a region considered to be free of Rhipicephalus sanguineus. Vet. Parasitol. 196: 189-193. http://dx.doi.org/10.1016/j.vetpar.2013.02.009

IBGE (Instituto Brasileiro de Geografia e Estatística) (2010). Censo Demográfico 2010. IBGE, Brasília.

Jain NC (1993). Essencials of Veterinary Hematology. 1st ed. Lea \& Febiger, Philadelphia.

Kelly PJ, Xu C, Lucas H, Loftis A, et al. (2013). Ehrlichiosis, babesiosis, anaplasmosis and hepatozoonosis in dogs from

Genetics and Molecular Research 15 (3): gmr.15038623 
St. Kitts, West Indies. PLoS One 8: e53450. http://dx.doi.org/10.1371/journal.pone.0053450

Lasta CS, Santos AP, Mello FPS, Lacerda LA, et al. (2009). Infecção por Hepatozoon canis em canino doméstico na região Sul do Brasil confirmada por técnicas moleculares. Cienc. Rural 39: 2135-2140. http://dx.doi.org/10.1590/ $\underline{\text { S0103-84782009005000160 }}$

Marchetti V, Lubas G, Baneth G, Modenato M, et al. (2009). Hepatozoonosis in a dog with skeletal involvement and meningoencephalomyelitis. Vet. Clin. Pathol. 38: 121-125.http://dx.doi.org/10.1111/j.1939-165X.2008.00080.x

Menn B, Lorentz S and Naucke TJ (2010). Imported and travelling dogs as carriers of canine vector-borne pathogens in Germany. Parasit. Vectors 3: 34. http://dx.doi.org/10.1186/1756-3305-3-34

Miyama T, Sakata Y, Shimada Y, Ogino S, et al. (2005). Epidemiological survey of Babesia gibsoni infection in dogs in eastern Japan. J. Vet. Med. Sci. 67: 467-471. http://dx.doi.org/10.1292/jvms.67.467

Mundim AV, Morais IA, Tavares M, Cury MC, et al. (2008). Clinical and hematological signs associated with dogs naturally infected by Hepatozoon sp. and with other hematozoa: a retrospective study in Uberlândia, Minas Gerais, Brazil. Vet. Parasitol. 153: 3-8.http://dx.doi.org/10.1016/j.vetpar.2008.01.018

Mylonakis ME, Leontides L, Gonen L, Billinis C, et al. (2005). Anti-Hepatozoon canis serum antibodies and gamonts in naturally-occurring canine monocytic ehrlichiosis. Vet. Parasitol. 129: 229-233. http://dx.doi.org/10.1016/j. vetpar.2005.01.012

O’Dwyer LH (2011). Brazilian canine hepatozoonosis. Rev. Bras. Parasitol. Vet. 20: 181-193. http://dx.doi.org/10.1590/ $\underline{\text { S1984-29612011000300002 }}$

O'Dwyer LH, Massard CL and Pereira de Souza JC (2001). Hepatozoon canis infection associated with dog ticks of rural areas of Rio de Janeiro State, Brazil. Vet. Parasitol. 94: 143-150. http://dx.doi.org/10.1016/S0304-4017(00)00378-2

O'Dwyer LH, Saito ME, Hasegawa MY and Kohayagawa A (2006). Prevalence, hematology and serum biochemistry in stray dogs naturally infected by Hepatozoon canis in São Paulo. Arq. Bras. Med. Vet. Zoo. 58: 688-690. http://dx.doi. org/10.1590/S0102-09352006000400039

Otranto D, Dantas-Torres F, Weigl S, Latrofa MS, et al. (2011). Diagnosis of Hepatozoon canis in young dogs by cytology and PCR. Parasit. Vectors 4: 55-60. http://dx.doi.org/10.1186/1756-3305-4-55

Paludo GR, Dell'Porto A, de Castro e Trindade AR, McManus C, et al. (2003). Hepatozoon spp.: report of some cases in dogs in Brasília, Brazil. Vet. Parasitol. 118: 243-248. http://dx.doi.org/10.1016/j.vetpar.2003.10.009

Ramos R, Ramos C, Araújo F, Oliveira R, et al. (2010). Molecular survey in genetic characterization of tick-borne pathogens in dogs in metropolitan Recife (northeastern Brazil). Parasitol. Res. 107: 1115-1120. http//dx.doi. org/10.1007/s00436-010-1979-7

Rubini AS, dos Santos Paduan K, Von Ah Lopes V and O'Dwyer LH (2008). Molecular and parasitological survey of Hepatozoon canis (Apicomplexa: Hepatozoidae) in dogs from rural area of Sao Paulo state, Brazil. Parasitol. Res. 102: 895-899. http://dx.doi.org/10.1007/s00436-007-0846-7

Rubini AS, Paduan KS, Martins TF, Labruna MB, et al. (2009). Acquisition and transmission of Hepatozoon canis (Apicomplexa: Hepatozoidae) by the tick Amblyomma ovale (Acari: Ixodidae). Vet. Parasitol. 164: 324-327. http:// dx.doi.org/10.1016/j.vetpar.2009.05.009

Sasaki M, Omobowale O, Ohta K, Tozuka M, et al. (2008). A PCR-based epidemiological survey of Hepatozoon canis in dogs in Nigeria. J. Vet. Med. Sci. 70: 743-745. http://dx.doi.org/10.1292/jvms.70.743

Spolidorio MG, Labruna MB, Machado RZ, Moraes-Filho J, et al. (2010). Survey for tick-borne zoonoses in the state of Espirito Santo, southeastern Brazil. Am. J. Trop. Med. Hyg. 83: 201-206. http://dx.doi.org/10.4269/ ajtmh.2010.09-0595

Spolidorio MG, Torres MdeM, Campos WNS, Melo ALT, et al. (2011). Molecular detection of Hepatozoon canis and Babesia canis vogeli in domestic dogs from Cuiabá, Brazil. Rev. Bras. Parasitol. Vet. 20: 253-255. http://dx.doi. org/10.1590/S1984-29612011000300015

Vojta L, Mrljak V, Curković S, Zivicnjak T, et al. (2009). Molecular epizootiology of canine hepatozoonosis in Croatia. Int. J. Parasitol. 39: 1129-1136. http://dx.doi.org/10.1016/j.ijpara.2009.02.007

Genetics and Molecular Research 15 (3): gmr.15038623 